\title{
Implementasi Pendidikan Karakter pada Pembelajaran Jarak Jauh di Era Pandemi Covid-19 di Sekolah Dasar
}

\author{
Maman Surahman, Siska Mega Diana, Dayu Rika Perdana \\ Pendidikan Guru Sekolah Dasar,Universitas Lampung \\ Jl. Prof. Dr. Ir. Sumantri Brojonegoro No.1, Gedong Meneng, Kota Bandar Lampung \\ E-mail: maman.surahman@fkip.unila.ac.id
}

\begin{abstract}
Article Info
Received Oktober 2021

Accepted November 2021

Published November 2021

Keywords:

Character Education,

Distance Learning, Amid

COVID-19

\section{Abstract}

Distance Learning (Pembelajaran Jarak Jauh/PJJ) is a transition to faceto-face teaching and learning activities in a school setting, in which due to the COVID-19 pandemic education is experiencing challenges, especially in formal education and school activities must be conducted offline and online. Currently, distance learning is determining key to continuing education. Regardless of the circumstance and condition of each student, they must be provided with an optimal education. Hence, nowadays, it is important to instill and maintain character in students that in any circumstances, education is an absolute term. The purpose of this study was to investigate the implementation of character education in distance learning amid the COVID-19 pandemic in elementary school. This research used a qualitative descriptive. The results of character education research can develop life skills or student skills in the learning process, in this case how students can be responsible for each assignment, as well as discipline in participating in distance learning.
\end{abstract}

\begin{abstract}
Abstrak : Pembelajaran Jarak Jauh (PJJ) merupakan sebuah transisi kegiatan belajar mengajar dari yang harusnya dilakukan secara tatap muka di sekolah, namun karena adanya pandemi Covid-19 dunia pendidikan menghadapi tantangan baru khususnya di pendidikan formal sehingga kegiatan sekolah pun harus dialihkan baik secara luring maupun daring. Dalam kondisi dunia saat ini, pembelajaran jarak jauh lah yang menjadi kunci utama dalam terus melakukan pendidikan. Bagaimanapun keadaan dan kondisi setiap peserta didik, mereka tetap wajib mendapatkan pendidikan secara optimal. Maka pada era saat ini penting untuk tetap menanamkan dan menjaga karakter pada peserta didik bahwa apapun keadaannya pendidikan tetaplah menjadi hal yang utama. Tujuan dari penelitian ini adalah untuk mengetahui bagaimana implementasi pendidikan karakter pada pembelajaran jarak jauh di era pandemi Covid-19 di sekolah dasar. Penelitian ini menggunakan jenis penelitian deskriptif kualitatif. Hasil penelitian pendidikan karakter dapat mengembangkan life skill atau kecakapan peserta didik dalam proses pembelajaran, dalam hal ini bagaimana peserta didik dapat bertanggung jawab terhadap setiap penugasan yang diberikan, juga kedisiplinan dalam mengikuti pembelajaran jarak jauh.
\end{abstract}

Kata Kunci: Pendidikan Karakter, Pembelajaran Jarak Jauh, Pandemi Covid-19

C2021 Jurusan Ilmu Pendidikan, FKIP Universitas Lampung 


\section{PENDAHULUAN}

Pembelajaran merupakan suatu proses yang dilalui oleh setiap orang. Pembelajaran tidak hanya terjadi pada instansi pendidikan seperti sekolah, tetapi pembelajaran dapat terjadi dimana saja. Pada Era Pandemi Covid-19 seperti yang saat ini terjadi di dunia tak terkecuali Indonesia, dunia pendidikan menghadapi tantangan baru khususnya di pendidikan formal sehingga kegiatan sekolah pun mau tidak mau harus dialihkan atau diselenggarakan dalam jaringan (daring). Tujuan pendidikan adalah tujuan intruksional yang harus dicapai setelah proses pembelajaran ke dalam lima kategori yakni verbal information, attitudes, intellectual skill, motoric skill dan cognitive strategy (Hamalik, 2016). Semua tujuan itu mengarah pada proses, tingkah laku, penampilan, ekspresif dan pribadi setiap individu. Pembiasaan tersebut harus dilakukan sejak dini karena jika tidak ditanamkan sejak dini sejak masih sekolah dasar, maka tujuan itu akan membutuhkan lebih banyak waktu dan pembiasaan.

Era pandemi Covid-19 ini telah mengubah seluruh aspek kehidupan manusia, khususnya dalam dunia pendidikan. Keadaan ini mengharuskan semua elemen pendidikan untuk beradaptasi dan kembali menanamkan nilainilai yang sebelumnya ditanamkan di sekolah. Jika kita lihat saat ini peserta didik sekolah dasar yang melalukan pembelajaran dalam jaringan cenderung kurang menanamkan nilai-nilai pendidikan karakter, seperti gaya berbicara yang kurang santun terhadap guru maupun teman sebaya, kurang disiplin dalam mengumpulkan pekerjaan rumah dan lain sebagainya. Seperti yang telah disebutkan di atas, hal itu terjadi karena kurangnya penanaman nilainilai pendidikan karakter dan kurangnya perhatian yang diberikan oleh orang tua.

Pandemi Covid-19 mendesak pengujian pendidikan jarak jauh yang hampir belum pernah dilakukan secara serempak sebelumnya, Sun et al (2020) bagi semua elemen pendidikan yakni peserta didik, guru dan orang tua. Mengingat bahwa di era pandemi, waktu, lokasi, dan jarak menjadi permasalahan besar saat ini (Kusuma \& Hamidah, 2020) sehingga pembelajaran jarak jauh menjadi solusi untuk mengatasi kesulitan dalam melaksanakan pembelajaran secara tatap muka. Walaupun sebenarnya 
pembelajaran jarak jauh (PJJ) ini tidak mudah untuk dilakukan, bahkan berbeda hampir 80 derajat dengan pembelajaran tatap muka (face to face). Perbedaan yang paling mendasar tentu peserta didik tidak dapat melakukan interaksi secara langsung dengan guru (Teguh, 2015). Pembelajaran jarak jauh menuntut para peserta didik untuk dapat menggunakan teknologi dan internet, mereka harus bergantung pada jaringan dan teknologi jika pembelajaran yang dilakukan berbasis dalam jaringan internet (daring). Dan inilah yang dialami peserta didik sekarang terutama peserta didik sekolah dasar karena lebih banyak berinteraksi di rumah dan berteman dengan teknologi yang mengakibatkan mereka mengetahui hal yang seharusnya belum mereka ketahui lalu kemudian membentuk karakter yang kurang baik.

Pemahaman terhadap karakter memang terbilang relatif dan berbedabeda tergantung dari cara pandang seseorang dalam menilai. Karakter sangat dipengaruhi oleh lingkungan dimana individu atau para peserta didik tumbuh dan berkembang. Anak yang tumbuh dan berkembang dalam lingkungan moral yang baik akan tumbuh dan memiliki karakter yang baik, tetapi jika sebaliknya maka ia akan memiliki karakter yang tidak sesuai dengan yang terdapat di dalam masyarakat. Dan hal inilah yang harus ditekankan oleh guru dan orang tua dalam memberikan pendidikan kepada putra putri mereka, terutama di era pandemi Covid-19.

Maka dalam hal penanaman itu kita membutuhkan strategi dalam menanamkan pendidikan pada era pandemi saat ini, yakni diantaranya adalah menumbuhkan nilai karakter disiplin seperti tertib dan patuh pada berbagai peraturan dan ketentuan yang berlaku baik di dalam keluarga, masyarakat ataupun negara. Dan strategi lainnya seperti menumbuhkan nilai karakter kreatif dengan serangkaian kegiatan kreatif, menumbuhkan nilai karakter mandiri dengan tidak bergantung pada orang lain dan mempergunakan segala kemampuan yang dimiliki, dan yang terakhir adalah menumbuhkan nilai karakter tanggung jawab yang berupa integritas yang dimiliki oleh seseorang.

Berlakunya Peraturan Menteri Pendidikan dan Kebudayaan Indonesia No. 4 Tahun 2020 tentang pembelajaran jarak jauh guna mencegah penyebaran Covid-19, mengisyaratkan pembelajaran yang mengkolaborasikan peran guru, siswa dan orang tua dalam proses pembelajaran. Dari kaca mata pendidikan, dimasa pandemi seperti sekarang ini adalah kesempatan baik untuk orang tua 
terlibat secara langsung dalam proses pembelajaran. Pendidikan karakter merupakan hal yang penting dalam proses pertumbuhan dan memupuk jati diri peserta didik melalui proses pembelajaran. Pendidikan karakter memiliki 3 fungsi utama yakni, (1) pembentukan dan pengembangan potensi agar peserta didik berpikiran baik, berhati baik dan berprilaku sesuai dengan falsafah pancasila. (2) perbaikan dan penguatan dalam peran keluarga, satuan pendidikan, masyarakat, dan pemerintah untuk ikut berpartisipasi dan bertanggung jawab dalam pengembangan potensi warga negara dan pembangunan bangsa menuju bangsa yang maju, mandiri dan sejahtera. (3) penyaring untuk memilah budaya bangsa sendiri dan menyaring budaya bangsa lain yang tidak sesuai dengan nilai-nilai budaya bangsa dan karakter bangsa yang bermartabat (Santika, 2020). Maka dalam pelaksanaan pembelajaran jarak jauh pada masa pandemi ini 3 fungsi utama pendidikan karakter tersebut harus terus ditanamkan dan ditumbuhkan pada peserta didik. Keberhasilan dalam implementasi pendidikan karakter pada era pandemi Covid-19 membutuhkan peran utama orang tua peserta didik dan lingkungan rumah sebagai mitra sekolah dalam usaha Nation and Character Building (Santika, 2020). Maka urgensi dalam penelitian ini adalah mengimplementasikan pendidikan karakter pada Pendidikan Jarak Jauh (PJJ) sebagai alternatif yang paling ampuh untuk tetap terselenggaranya pendidikan yang menarik dan menyenangkan selama daring di sekolah dasar.

\section{METODE}

\section{Desain penelitian}

Untuk mengungkap implementasi pendidikan karakter di era pandemi Covid-19 pada pembelajaran jarak jauh di SD Negeri 10 Metro Timur dengan unsur-unsur pokok yang harus ditemukan sesuai dengan butir-butir rumusan masalah, tujuan dan kegunaan penelitian, maka dalam penelitian ini menggunakan pendekatan kualitatif. Adapun jenis metode penelitian kualitatif yang digunakan dalam penelitian ini yaitu metode deskriptif kualitatif. 


\section{Subjek Penelitian}

Subjek yang akan dijadikan informan diantanya: kepala sekolah, tenaga pendidik, guru kelas, guru mata pelajaran pendidikan karakter (PPKn dan Agama), dan peserta didik.

\section{Instrumen penelitian}

Kehadiran peneliti sangat penting dalam penelitian ini karena peneliti adalah instrumen dalam penelitian. Peneliti melakukan observasi secara langsung melalui wawancara. Wawancara juga dilakukan ketika peserta didik berada di rumah mereka masing-masing dengan cara mendatangi rumah peserta didik yang mudah dijangkau atau dekat. Peneliti mengikuti pembelajaran yang dilakukan secara daring untuk mengamati proses implementasi pendidikan karakter pada pembelajaran jarak jauh dan mengamati hal yang berkaitan dengan implementasi pendidikan karakter selama proses pembelajaran.

\section{Analisis data}

Dalam penelitian ini teknik yang digunakan untuk pengumpulan data yakni, angket, wawancara, dan dokumentasi. Teknik pengolahan data dalam penelitian ini mengadaptasi dari penelitian Sugiyono (2014), yaitu: editing, tabulating dan Coding,dan interpretasi data.

\section{HASIL DAN PEMBAHASAN}

Pendidikan karakter menjadi sesuatu yang penting bagi SD Negeri 10 Metro Timur karena karakter adalah ukuran kualitas peserta didik dari hasil selama mengikuti pembelajaran jarak jauh. Untuk itu di SD Negeri 10 Metro Timur, semua pendidik penting untuk memahami konsep pendidikan karakter agar dapat mengimplementasikan proses pengembangan dan penguatan karakter terhadap peserta didiknya dengan baik selama pembelajaran jarak jauh. Hasil data penelitian yang telah dilakukan berdasarkan wawancara dengan guru kelas di SD Negeri 10 MetroTimur adalah sebagai berikut.

a. Pada pandemi Covid-19 seperti ini, sebagai pendidik kita harus menguasai dunia teknologi. Dengan sekali klik kita sudah mendapatkan banyak informasi sehingga dapat menambah pengetahuan kita sebagai pendidik. Meskipun ilmu itu bisa bersumber dari apa saja. Namun pendidikan karakter tetap perlu kita tanamkan sebagai pendidik yang kemudian kita transfer ke peserta didik meski sulit dalam penerapannya 
tetap harus dibiasakan agar peserta didik menerapkan nilai-nilai karakter di lingkungan sekolah, keluarga, maupun pada lingkunganya.

b. Pendidikan karakter itu sangat penting ya bagi peserta didik, karena pada pandemi Covid-19 ini peserta didik lebih banyak melakukan aktivitas di rumah bersama orang tua. Faktanya, orang tua di rumah telah memasrahkan sekaligus memberi kepercayaan penuh ke pendidik untuk perkembangan karakter anaknya sedangkan selama pandemi ini harusnya yang lebih berperan adalah orang tua peserta didik karena pendidik terbatas waktu jika harus memantau langsung.

c. Saat ini banyak ditemukan peserta didik yang dnilai akademisnya baik tetapi kurang memiliki karakter yang baik. Maka pendidikan karakter sangat penting untuk ditanamkan sejak dini kepada peserta didik di sekolah dasar apalagi di masa pandemi seperti ini ya. Nilai akademik yang tinggi tidak akan menjamin apapun karena yang terpenting adalah karakter peserta didik apakah dia bisa membawa diri dalam lingkungan masyarakat.

Paparan pendapat guru kelas di SD Negeri 10 Metro Timur tersebut dapat disimpulkan bahwa pendidikan karakter penting dilakukan untuk peserta didik karena nilai akademik (kognitif) tidak dapat dijadikan sebagai pedoman penilaian, kenaikan kelas atau kelulusan. Peserta didik yang diharapkan adalah peserta didik yang berkarakter, berkualitas serta memiliki kuantitas. Peserta didik yang seperti itu akan lebih komplit karena dia mampu menempatkan dirinya di setiap suasana dan lingkungan. Agar karakter peserta didik dapat terbentuk secara baik maka dalam proses penanamannya membutuhkan kerjasama antar sekolah dan keluarga.

Pendidikan karakter di SD Negeri 10 Metro Timur dapat diimplementasikan melalui Pembelajaran Jarak Jauh (PJJ). Pendidik mempunyai peran dalam mengembangkan nilai- nilai karakter pada diri peserta didik melalui implementasi pembelajaran dengan unsur-usur pengembangan karakter meski pada Pembelajaran Jarak Jauh. Hasil observasi dan wawancara dengan tiga guru kelas menunjukan beliau telah mengimplementasikan dengan cara menyelipkan nilai-nilai karakter pada Pembelajaran Jarak Jauh yang dilakukan.

a. Pengimplementasian itu saya lakukan dalam bentuk menyelipkan nilainilai karakter saat penyampaian materi pembelajaran jarak jauh. Kita dapat memilih nilai karakter mana yang cocok untuk dimasukkan dalam materi. Misalnya, nilai karakter cinta tanah air saya selipkan pada materi Bahasa Indonesia pada materi bangga menggunakan/berbicara menggunakan bahasa Indonesia. 
b. Penyisipan nilai-nilai karakter kepada peserta didik bisa juga dibiasakan saat berdoa sebelum memulai dan selesai belajar/pembelajaran. Tentu sebagai pendidik, saya tidak bosan untuk selalu mengingatkan kepada peserta didik untuk berperilaku baik dalam pembelajaran jarak jauh ini.

c. Memang PJJ ini sangat memiliki tantangan berat, karena sulit untuk menanamkan pendidikan karakter pada peserta didik kalau tidak didukung oleh wali peserta didik dari rumah. Maka kita semua harus bersinergi dalam menanamkan pendidikan karakter ini. Saya memiliki kekhawatiran jika terlalu menekankan ini semua tanpa dukungan orang tua.

d. Dalam bahan ajar yang saya gunakan salah satunya buku tematik. Peserta didik diusahakan dapat memperkaya pengetahuannya melalui internet maupun sumber lain. Pengimplementasiannya misalnya dengan cara memberikan materi yang kemudian saya minta peserta didik untuk membaca dan memahami materi tersebut. Lalu dipertemuan selanjutnya saya berikan beberapa pertanyaan dari materi yang telah diberikan. Maka disini saya dapat melihat karakter tanggung jawab, displin, dan jujur dari peserta didik.

Pernyataan beberapa guru kelas di SD Negeri 10 Metro Timur mengenai cara mengimplementasikan pendidikan karakter pada Pembelajaran Jarak Jauh dapat disimpulkan bahwa pendidik mengimplementasikan pendidikan karakter pada Pembelajaran Jarak Jauh dengan cara menyesuaiakan, memodifikasi dan menyisipkan nilai-nilai karakter pada setiap materi pada saat pembelajaran. Nilai-nilai karakter yang termuat misalnya meliputi nilai karakter cinta tanah air, tanggung jawab, disiplin, dan jujur pada materi. Serta dapat disimpulkan bahwa bahan ajar digunakan di SD Negeri 10 Metro Timur untuk menunjang pendidikan karakter pada Pembelajaran Jarak Jauh dari buku, internet, youtube dan media pembelajaran lainya yang dijadikan sumber belajar. Pendidik menggunakan bahan ajar yang memuat pendidikan karakter pada standar kompetensinya yaitu buku tematik yang dimiliki oleh peserta didik. Pendidik SD Negeri 10 Metro Timur menggunakan literatur dari internet sebagai materi perluasan dan tambahan untuk peserta didik, bahan ajar yang digunakan memuat pendidikan karakter.

Pendidikan karakter juga dapat dilakukan melalui model Pembelajaran Jarak Jauh yang mendukung. SD Negeri 10 Metro Timur menetapkan platform zoom selain itu juga ada platform whatsapp sebagai media pembelajaran. Pendidik diberikan kebebasan untuk menggunakan platform 
lainnya dan menggunakan model pembelajaran yang dianggap paling efektif. Berikut adalah data dari penelitian di SD Negeri 10 Metro Timur.

a. Model pembelajaran yang saya terapkan biasanya sederhana saja, namanya juga masih SD yang penting sudah bisa mencakup penguasaan materi. Yang saya lihat adalah tanggung jawab peserta didik pada proses pembelajaran jarak jauh. Apalagi saya maemakai aplikasi Zoom. Mereka bisa melakukan diskusi kecil dengan metode ceramah yang saya lakukan terlebih dulu. Disitu saya mencari kesulitan yang dihadapi peserta didik. Saya tetap memberikan penguatan dan menanyakan apakah ada materi yang belum dipahami ketika pembelajaran jarak jauh dengan paltform zoom.

b. Dalam zoom saya menggunakan PPT yang saya sharescreen kan dan saya putarkan lagu-lagu nasionalis terlebih dulu sebelum masuk pada materi. Antusias peserta didik lebih tinggi dan lebih fokus.

Dari data di atas dapat disimpulkan bahwa motodePembelajaran Jarak Jauh yang diterapkan SD Negeri 10 Metro Timur umumnya menggunakan metode tanya jawab, diskusi dan ceramah. Pendidik melakukan pembelajaran menggunakan platform zoom dan whatssapp untuk memberikan tugas, pendidik juga menggunakan PPT dan lagu-lagu nasional sebagai media pembelajaran agar peserta didik lebih fokus dan tertarik mengikuti pembelajaran daring. Pendidik memilih zoom sebagai platform yang digunakan dalam Pembelajaran Jarak Jauh karena zoom merupakan aplikasi yang mudah untuk diterapkan, pendidik dapat melihat perilaku peserta didik ketika proses pembelajaran melalui vitur kamera. Implementasi pendidikan karakter yang digunakan pendidik di SD Negeri 10 Metro Timur melalui keteladanan yang dicerminkan dari sosok pendidik sebagai etalase nilai-nilai karakter. Pembudayaan penanaman nilai karakter dilakukan melalui tata tertib. Penguatan nilai karakter melalui pemberian penghargaan kepada peserta didik yang mempunyai perilaku baik.

Pentingnya pendidikan karakter bagi SD Negeri 1 Metro Timur tidak terlepas dari tujuan pendidikan karakter yaitu membentuk pribadi peserta didik yang berkualitas dan beretika. Pendidik melakukan upaya pendidikan karakter dengan menerapkan strategi implementasi keteladanan, penguatan, pemberdayaan dan pembudayaan. 


\section{Keteladanan}

Pendidik di SD Negeri 10 Metro Timur melakukan implementasi kepada peserta didik dengan pembawaan sebagai sosok pendidik yang sabar. Implementasi pendidikan karakter lebih tepat dilakukan secara halus dan perlahan agar peserta didik dapat menerimanya dengan baik dan memberikan kesan nyaman dalam pembelajaran yang dilakukan. Pendidik berusaha menjadi sosok teladan bagi peserta didik dengan karakter sabar dan disiplin. Karakter yang dapat diteladani dari pendidik adalah datang tepat waktu ketika kelas daring, memberikan konfirmasi ketika ada perubahan jam dan ketidakhadiran, berdoa dengan bersungguh-sungguh sebelum dan setelah Pembelajaran Jarak Jauh serta berpakaian rapi ketika mengajar.

\section{Penguatan}

Implementasi pendidikan karakter di SD Negeri 10 Metro Timur dilakukan menggunakan pendekatan penguatan dengan mengimplementasikan kegiatan pembelajaran pendidikan karakter. Pendidik dapat melakukan penguatan nilai karakter dengan melakukan doa bersama, menetapkan waktu pengumpulan tugas, mengkondisikan kelas dan peserta didik. Pendidik di SD Negeri 10 Metro Timur dalam upaya implementasi pendidikan karakter untuk peserta didiknya menjadi sosok pendidik yang friendly dan suka memberikan penghargaan kepada peserta didik yang berperilaku baik, sehingga menciptakan suasana pembelajaranmenyenangkan bagi peserta didik.

\section{Pemberdayaan dan Pembudayaan}

Implementasi pemberdayaan dan pembudayaan nilai-nilai karakter dapat dilakukan dengan memberlakukan tata tertib, peraturan dan norma di lingkungan sekolah. SD Negeri 10 Metro Timur memberlakukan tata tertib yang wajib dipatuhi seluruh peserta didik. Pendidik juga mempunyai tata tertib khusus yang diterapkan dalam pembelajaran. Pendidik memberlakukan peraturan dan tata tertib sebagai pendekatan implementasi pendidikan karakter terhadap peserta didik. Tujuan implementasi mengguakan peraturan adalah membentuk peserta didik yang patuh dan disiplin ketika mengikuti Pembelajaran Jarak Jauh. Pendidik menekakankan peserta didik untuk 
melakukan perilaku yang baik agar mereka terbiasa melakukan perilakuperilaku positif seperti mengerjakan tugas tepat waktu, datang tepat waktu, dan mengikuti pembelajaran dari awal hingga akhir sehingga mereka dapat menjadi lebih berkarakter memiliki sifat kemandirian, disiplin dalam dirinya serta dapat lebih menghargai waktu.

\section{KESIMPULAN}

Berdasarkan hasil penelitian yang dilakukan dan pembahasan penelitian dapat disimpulkan sebagai berikut.

Pemahaman konsep pendidikan karakter di SD Negeri 10 Metro Timur adalah pendidikan karakter sebagai kualitas dari peserta didik, setinggi apappun nilai kognitif yang dicapai tanpa diiringi dengan perilaku yangbaik dalam keseharianya tidak dapat menunjukan kualitas pembelajaran yang telah diikuti peserta didik, guru kelas juga memahami pendidikan karakter merupakan proses untuk membentuk perilaku peserta didik dan mempersiapkan peserta didik berada pada lingkungan masyarakatnya, nilainilai karakter yang dikembangkan oleh pendidik diupayakan agar diterapkan peserta didik dalam keseharianya, pendidik mengimplementasikan pendidikan karakter melalui tiap mata pelajaran karena mempunyai karakteristik sebagai pembelajaran yang tidak menekankan keberhasilan pada pengetahuan saja tetapi juga sangat memperhatikan pada pencapaian nilai karakter dan keterampilan.

Implmentasi pendidikan karakter melalui pembelajaran daring padamata pelajarandi SD Negeri 10 Metro Timur telah berjalan cukup baik, pendidik melakukan pengembangan nilai karakter kepada peserta didik dengan memodifikasi dan menyelipkan nilai karakter pada setiap kegiatan penutup. Pendidik melakukan pendidikan karakter dengan membiasakan peserta didik berperilaku sesuai nilai karakter.

\section{DAFTAR PUSTAKA}

Hamalik, Oemar. (2005). Proses Belajar Mengajar. Jakarta: PT. Bumi Aksara. https://dspace.uc.ac.id/handle/123456789/907.

Santika, I. W. E. (2020). Pendidikan karakter pada pembelajaran daring. Indonesian Values and Character Education Journal, 3(1), 8-19. 
Kusuma, J. W., \& Hamidah. (2020). Platform Whatsapp Group Dan Webinar Zoom Dalam Pembelajaran Jarak Jauh Pada Masa Pandemik Covid 19. Jurnal Ilmiah Pendidikan Matematika Volume, 5(1).

Sugiyono. (2014). Metode Penelitian Kuantitatif Kualitatif dan $R \& D$. Bandung: Alfabeta.

Sun, L., Tang, Y., \& Zuo, W. (2020). Coronavirus pushes education online. Nature Materials, 19(6), 687-687.

Teguh, M. (2015). Difusi Inovasi dalam Program Pembelajaran Jarak Jauh di Yayasan Trampil Indonesia. Lembaga Penelitian dan Pengabdian Kepada Masyarakat Universitas Kristen Petra. 